\title{
Partial resection of giant rhabdomyoma of the right ventricle in a neonate
}

\author{
Laurynas Bezuška1 ${ }^{1}$, Virgilijus Lebetkevičius ${ }^{1,2}$, Kęstutis Lankutis², Virgilijus Tarutis ${ }^{1,2}$ \\ ${ }^{1}$ Department of Cardiovascular Medicine, Vilnius University, Lithuania \\ ${ }^{2}$ Vilnius University Hospital Santariskiu Klinikos, Centre of Cardiac Surgery, Vilnius, Lithuania
}

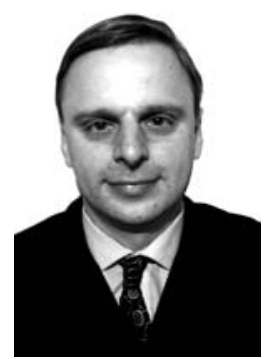

Kardiochirurgia i Torakochirurgia Polska 2013; 10 (4): 419-421

\begin{abstract}
Tumors are rare in neonates. The most common type is a benign rhabdomyoma. Rhabdomyoma is self-regressing with time. However, if a tumor is huge and causing hemodynamic instability, surgery is indicated. We present successful cardiac surgery for partial removal of a giant rhabdomyoma tumor in the right ventricle of a 7-day-old neonate and spontaneous regression of the remnant tumor mass at follow-up.

Key words: cardiac rhabdomyoma, tumors in neonates.
\end{abstract}

\section{Introduction}

The most common type of tumor in neonates is rhabdomyoma. It is a benign tumor which tends to spontaneous regression. $50-80 \%$ of cases of this tumor are associated with tuberous sclerosis [1]. Rhabdomyomas are usually small, multiple ventricular masses. Very rarely these tumors are symptomatic in infancy. The first line treatment should be conservative. If a tumor is very large and causing cardiac outflow obstruction, persistent arrhythmias or cardiogenic emboli, cardiac surgery is indicated [2]. However, surgery often is a big challenge due to tumor size and position and small patients. We present a successful partial excision of a huge rhabdomyoma in the right ventricle in a 7-day-old neonate and spontaneous regression of the remnant tumor mass at follow-up.

\section{Case report}

A term newborn $(3.1 \mathrm{~kg}, 50 \mathrm{~cm}$, body surface area $0.21 \mathrm{~m}^{2}$ ) with prenatal echocardiographic diagnosis of a mass in the right ventricle was admitted to our tertiary cardiac surgery centre just a few hours after birth. The patient presented with paroxysmal supraventricular tachycardia with heart rate of up to 240 beats per minute and hypoxia with saturation of $80 \%$. Chest x-ray demonstrated cardiomegaly with a cardiothoracic index of 0.75 (Fig. 1).

\section{Streszczenie}

Guzy serca występują u noworodków bardzo rzadko. Najczęściej spotykanym jest mięśniak poprzecznie prążkowany (łac. rhabdomyoma), który w większości przypadków zanika samoistnie. Gdy guz jest bardzo duży i utrudnia napływ lub odpływ krwi, wskazane jest leczenie chirurgiczne. Autorzy pracy prezentują przypadek skutecznej częściowej resekcji mięśniaka poprzecznie prążkowanego u siedmiodniowego noworodka i całkowitego zaniknięcia pozostałej części guza.

Słowa kluczowe: rhabdomyoma serca, guzy u noworodków.

Transthoracic echocardiography (TTE) confirmed a large cardiac mass located in the right ventricle and attached to the intraventricular wall (Fig. 2A). A computed tomography (CT) scan showed a single giant mass $(33 \times 21 \times 20 \mathrm{~mm})$ in the right ventricle with no contrast between the mass and ventricular septum (Fig. 3). The first week of conservative treatment with prostaglandin infusion (for patent ductus arteriosus), amiodarone, lidocaine, and oxygen therapy was not sufficient. The patient was deteriorating due to inadequate blood flow through the right ventricle and repetitive paroxysmal supraventricular tachycardia. At 7 days of life, the patient was scheduled for surgical resection of the cardiac tumor. A median sternotomy and bicaval cannulation was performed. A patent ductus arteriosus was clipped and cardiopulmonary bypass initiated. The tumor mass was attached to the intraventricular wall and occupied more than $80 \%$ of the right ventricle. It was protruding through the tricuspid valve to the right atrium. The tumor was partially excised. Complete tumor removal was impossible due to its large size and penetration to the ventricular septum. The tricuspid valve was insufficient, so valvuloplasty was performed. Cardiopulmonary bypass time was 80 min and aortic cross clamp time was $41 \mathrm{~min}$. The patient was successfully weaned off cardiopulmonary bypass after $28 \mathrm{~min}$ of reperfusion. Histopathologic and 


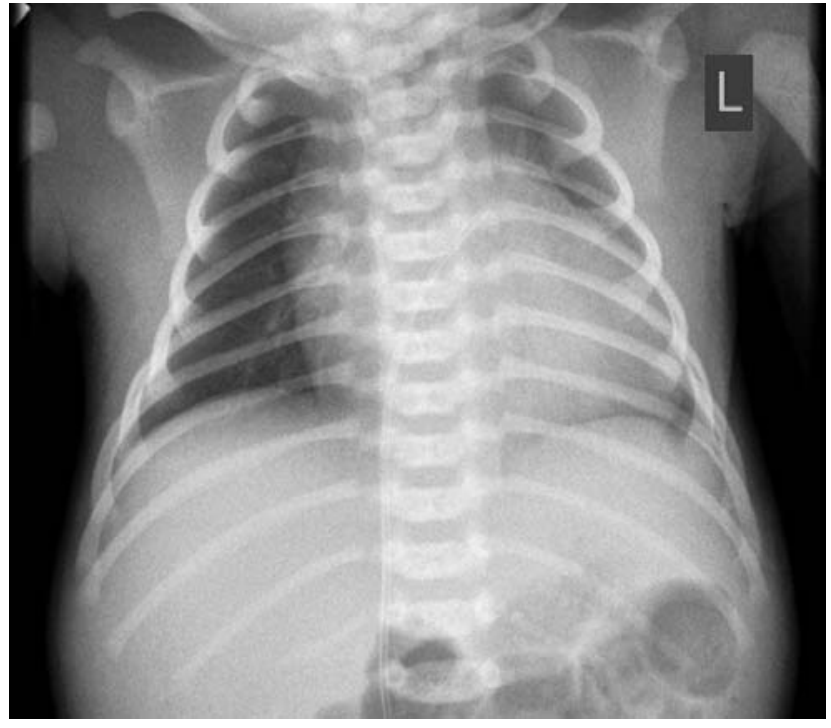

Fig. 1. Postnatal chest $x$-ray. The cardiac silhouette is dilated (cardiothoracic index, 0.75)

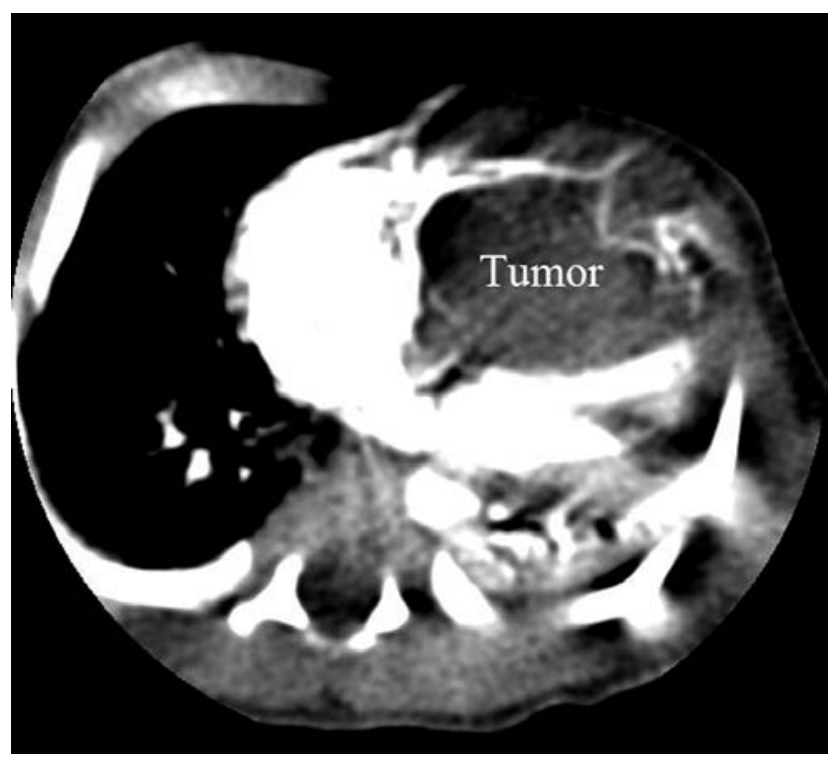

Fig. 3. Axial contrast material-enhanced CT scan shows a large mass in the right ventricle

immunohistochemical studies confirmed the diagnosis of cardiac rhabdomyoma. The neonate required mechanical ventilation for 30 hours and it was discharged from the intensive care unit (ICU) on the 19th postoperative day. Postoperative tachyarrhythmia was the reason for long stay in the ICU. TTE for the first weeks after surgery showed a residual small mass penetrating the intraventricular septum and tricuspid valve without stenosis and moderate regurgitation (Fig. 2B). Tachycardia was treated with amiodarone and digoxin. The patient was discharged home on the 42nd postoperative day. At 10-month follow-up the baby was in a good clinical condition and transthoracic echocardiography showed good function of ventricles with diminished tumor mass and mild tricuspid valve regurgitation (Fig. 2C).
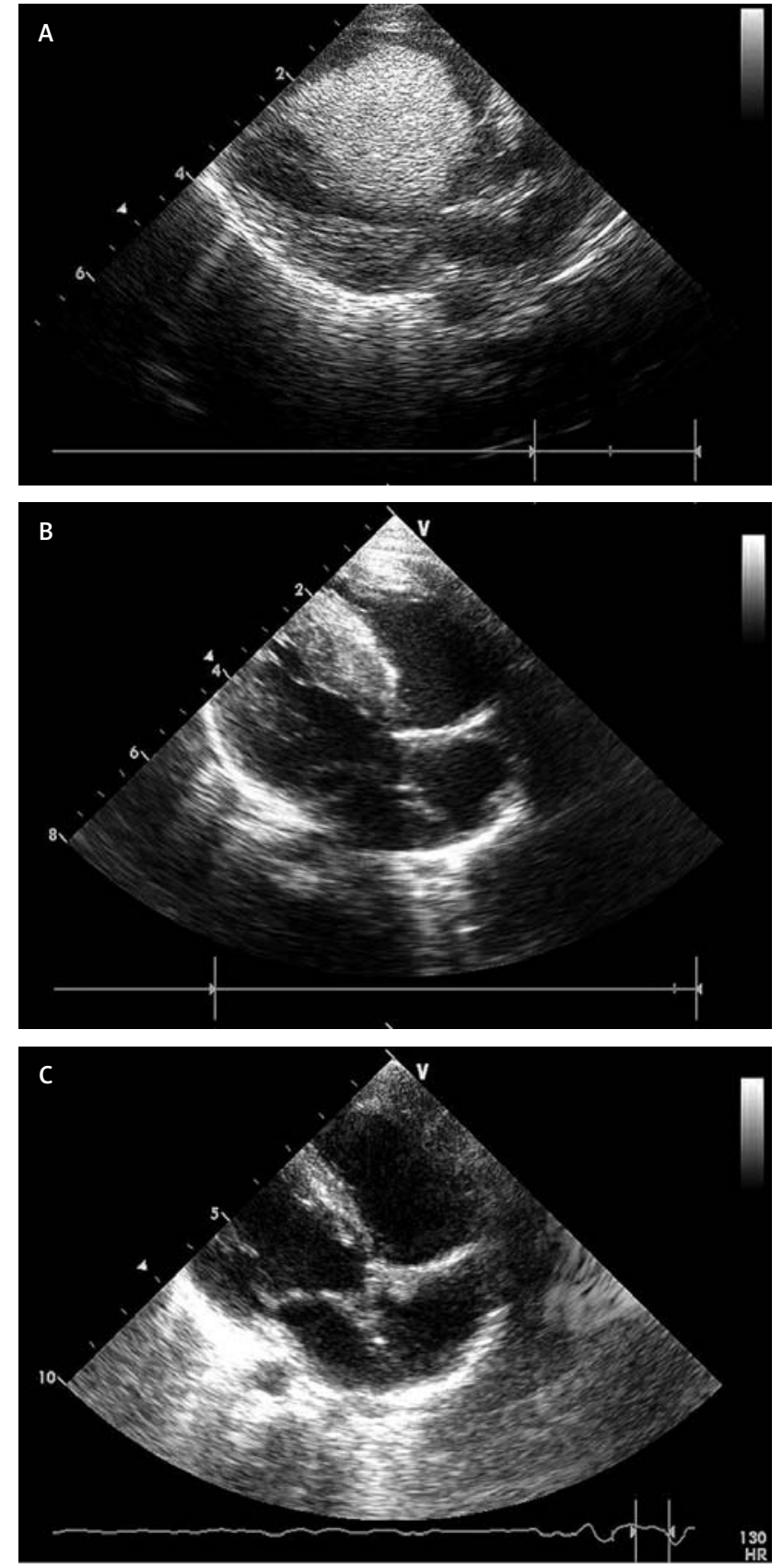

Fig. 2A-C. Transthoracic echocardiography image of: (A) a giant rhabdomyoma in the right ventricle before the surgery; (B) residual masses just after the surgery; and (C) diminished tumor at 10-month follow up

Work-up for tuberous sclerosis, including neurological investigation, renal ultrasound, and ophthalmologic exam, have thus far remained negative.

\section{Discussion}

The frequency of primary cardiac tumors is approximately $0.02 \%$ [3]. Even rarer are symptomatic rhabdomyomas in neonates [2]. They can be life-threatening because of their position, and can mimic not only structural cardiac disease but also arrhythmia and intermittent cyanosis [4]. The necessity for tumor resection in neonates is very spo- 
radic [1]. In our center pediatric cardiac surgery started in the 1960s. But this is the only case of surgery for giant rhabdomyoma in a neonate in our center.

The propensity for spontaneous regression of these tumors indicates medical therapy $[5,6]$. The time of rhabdomyoma spontaneous involution is varied. Some of the studies report sluggish resolution of rhabdomyoma in infancy [7] and Whiteside et al. even report postnatal growth of rhabdomyoma prior to tumor regression [8]. Hemodynamic compromise or intractable arrhythmias necessitate surgical intervention in infancy [2]. Chao et al. report that large tumor size (diameter $>20 \mathrm{~mm}$ ) and fetal dysrhythmia are significantly associated with increased perinatal and neonatal morbidity [9]. As rhabdomyomas tend to resolve with time, a complete resection of the tumor is not obligatory, especially, as in our patient, if it penetrates the heart muscle and the size of the tumor is huge. The most important is restoration of the best possible hemodynamic heart function [4]. Partial removal of the rhabdomyoma not only can facilitate the procedure, but also heart muscle tissues are preserved. Reduction of the residual tumor-like mass was observed at ten months follow-up in our case.

In pediatric cardiac tumors, the indication for surgery is differentiated according to the severity of the clinical picture. In contrast, in adult myxomas there is a consensus that surgical resection is the therapy of choice. Therapy should be individualized in pediatrics. The necessity and time of surgery should be decided according to the tumor size and time of regression and symptoms of the pediatric patient [4]. In our case we decided first to treat the patient conservatively with antiarrhythmic agents, prostaglandin infusion, and oxygen therapy. As this treatment was not efficient the surgery was performed. A good result was achieved.

\section{References}

1. Webb DW, Thomas RD, Osborne JP. Cardiac rhabdomyomas and their association with tuberous sclerosis. Arch Dis Child 1993; 68: 367-370.

2. De Rosa G, De Carolis MP, Pardeo M, Bersani I, Tempera A, De Nisco A, Caforio L, Romagnoli C, Piastra M. Neonatal emergencies associated with cardiac rhabdomyomas: an 8-year experience. Fetal Diagn Ther 2011; 29: 169-177.

3. Reynen K. Frequency of primary tumors of the heart. Am J Cardiol 1996; 77: 107.

4. Stiller B, Hetzer R, Meyer R, Dittrich S, Pees C, Alexi-Meskishvili V, Lange PE. Primary cardiac tumours: when is surgery necessary? Eur J Cardiothorac Surg 2001; 20: 1002-1006.

5. Fesslova V, Villa L, Rizzuti T, Mastrangelo M, Mosca F. Natural history and long-term outcome of cardiac rhabdomyomas detected prenatally. Prenat Diagn 2004; 24: 241-248.

6. Kohut J, Krzystolik-Ładzińska J, Szydłowski L, Smoleńska-Petelenz J, Giec-Fuglewicz G, Pajak J. The diagnosis, clinical course and follow-up of children with cardiac tumours - a single-centre experience. Kardiol Pol 2010; 68: 304-309.

7. Atalay S, Aypar E, Uçar T, Altuğ N, Deda G, Teber S, Tutar E. Fetal and neonatal cardiac rhabdomyomas: clinical presentation, outcome and association with tuberous sclerosis complex. Turk J Pediatr 2010; 52: 481-487.

8. Whiteside W, Saba Z, Kurio G. Postnatal growth of rhabdomyoma prior to tumor regression. Pediatr Cardiol 2010; 31: 541-544.

9. Chao AS, Chao A, Wang TH, Chang YC, Chang YL, Hsieh CC, Lien R, Su WJ. Outcome of antenatally diagnosed cardiac rhabdomyoma: case series and a meta-analysis. Ultrasound Obstet Gynecol 2008; 31: 289-295. 